\title{
The Impact of Reflective Teaching Applications Supported by Edmodo on Prospective Teachers' Self-Directed Learning Skills
}

\author{
https://doi.org/10.3991/ijet.v12.i10.6993 \\ Cigdem Hursen ${ }^{(凶)}$, Funda Gezer Fasli \\ Near East University, Nicosia, Cyprus \\ cigdem.hursen@neu.edu.tr
}

\begin{abstract}
The purpose of this research is to determine the impact of reflective teaching applications supported by Edmodo on prospective teachers' selfdirected learning skills. Also, the views of prospective teachers' regarding the use of Edmodo in education, which is a social learning platform, are determined. For the research, both qualitative and quantitative data were collected from 36 prospective teachers within the scope of the "Teaching Practice" course. A 12-week application has been conducted online with the support of Edmodo; however, classroom settings using face-to-face learning methods have also taken place. The results of the research reveal that the reflective teaching applications supported by Edmodo had an impact on the prospective teachers' self-directed learning skills. Furthermore, the results indicate that the prospective teachers who participated in the research were extremely satisfied with the Edmodo applications.
\end{abstract}

Keywords—blended education, self-directed learner, social learning platform, teacher education, view

\section{$1 \quad$ Introduction}

Training individuals who have the ability follow modern developments and innovations and are capable of coping with these changes is one of the primary purposes of education. Similarly, when raising students to be lifelong learners, a characteristic that is required in modern society, it is essential that teachers are at the core of the process. Students can achieve success with the guidance of teachers who perform their duties in the most effective manner. In this respect, the significance of teacher education is as important today as it has been throughout the history of education. Flores [1] argued that teacher education is significantly important in the development of teachers as well as the teaching process. Similarly, De Jong [2] identified that teacher education is significantly important in terms of the manner that prospective teachers become capable of establishing a link between theory and practice. Özçınar [3], in the same vein, emphasized the importance of teacher education and added that teacher quality can only be improved by improving the quality of teacher education. 
The research regarding teacher education in the literature, however, emphasizes that there is a gap between theory and practice. The relevant research signals that there are numerous activities that are concerned with improving the knowledge, skills and attitudes of prospective teachers in the classroom applications. Also, it is stressed that different teaching approaches should be employed $[4,5,6,7]$. That being the case, in the last 20 years, the reflective teaching approach has become one of the most effective approaches that has been thoroughly investigated by researchers. Reflective thinking is the integration of reasoning and action. Therefore, it is defined as a process where new values can be established by aggregating past experiences, actions and theories [8]. John Dewey pioneered reflective learning in 1933. Following Dewey, in 1983. Schön focused on reflective learning and explained how reflective applications should be implemented [9]. Liou [10], argued that reflective applications are important elements of teacher education as they enable profound learning to take place. In a similar manner to Liou [10], Kilpatrick, Hart, Najee-Ullah and Mitchem [11] also claimed that teachers discover their teaching abilities and are provided with the opportunity to construct new information through the reflective teaching applications. Henderson [12] believed that reflective teachers can provide effective instruction and acknowledge decision-making responsibilities intentionally. Reflective teaching, which provides an important insight into the learning-teaching process, offers teachers the opportunity to develop their teaching applications in line with the needs of students [13]. At this point, Sarsar, Başbay and Başbay [14] claimed that, as these teaching applications develop, the effectiveness of the learning-teaching process increases, where social learning platforms also play a crucial role. It is believed that students can participate in permanent learning by means of social learning platforms. Social learning platforms reshape individuals' communication, interaction, cooperation and even the learning process. Such learning platforms enable students and teachers to reflect on what they have learnt as well as their teaching experiences $[15$, $16,17,18,19,20]$. Additionally, it is claimed that social platform applications underpin pedagogic approaches, such as active and social learning, applications, and learning groups [21]. It should also be mentioned that social network applications are regarded as highly significant for the self-directed learning skills of learners [22]. Won et al. [23], believed that social networks increase the productivity of users and, under this broad assertion, he alluded to Facebook, Edmodo and Twitter as particular examples of social network platforms. Similarly, Sarrab et al. [24] underlined the significance of Edmodo, which is an online mobile social learning platform and is generally defined as the Facebook for education and instruction providers. Sarrab et al. [24] defined Edmodo as a platform where teachers and students can interact, perform collaborative work and share their learning experiences. Also, the Edmodo platform offers both teachers and students the opportunity to access each other's works in an online environment. This moves the learning process beyond the traditional classroom as it is a free of charge and is a safe platform [24]. In a similar manner, Okaz [25] claimed that social network platforms such as Edmodo provide teachers with a student-centred and collaborative teaching environment. Again, Trust et al. [26] argued that platforms like Edmodo facilitate communication between teachers and students. In fact, Trust et al. [26] emphasised the significance of professional learning net- 
works. Edmodo is a contemporary e-learning platform among other ICT applications, which enables teachers [27] to spend productive time with their students and enables the students to connect with the people and resources required to be successful [28].

Edmodo is now being used in several domains by almost 32 million people, including teachers, educators as well as students and is perceptibly distinct from other existing social networks, as it helps educators and teachers to establish specific strategies with the learners regarding online working [29]. However, relevant literature indicates that learners often experience problems in managing their learning process over online platforms and ultimately are unsuccessful $[22,30,31]$. In a similar vein, Ali [32] revealed in his research that some students have negative attitudes towards the use of Edmodo. Ali [32] claimed that teachers can have a considerably significant impact upon the level of students' use of Edmodo. Therefore, in this current research, the aim is to provide prospective teachers with experience of using and directing the online platform Edmodo. Also, the objective is to determine the impact of Edmodosupported reflective teaching applications on the self-directed learning skills of prospective teachers. To reach this aim, answers are sought to the following research questions:

1. Do the Edmodo supported reflective teaching applications have any significant impact on the self-directed learning pre-test point and post-test point averages of the prospective teachers?

2. What are the views of the prospective teachers regarding the Edmodo-supported reflective teaching applications?

\section{Method}

In this research, both qualitative and quantitative research techniques are employed. Additionally, this research is a case study where answers are sought to certain questions during the process of determining the impact of the Edmodo-supported reflective teaching applications on self-directed learning skills.

\subsection{Research participants}

This research is conducted with 36 prospective teachers studying at Near East University, which is located in Northern Cyprus. Although only prospective teachers who volunteered to participate were included, the size of the group was considered sufficient. Furthermore, only prospective teachers in the final year of the study at Near University were included in the research. The principal reason for selecting final year students as participants was that they had already completed the majority of their courses regarding the teaching profession. It is considered that final year prospective teacher students are more equipped in terms of their professional knowledge and skills when compared with students from lower years as they have completed most of the courses in teacher training programmes. All the participants who took part in the 12-week application were Turkish Cypriots. The applications were conducted in the Turkish language, which was the native language of the participants. The research 
was composed of $17(47.2 \%)$ female students and $19(52.8 \%)$ male students. The average age of the prospective teachers was 22. After graduation, the prospective teachers' objective is to assume teaching positions in high schools in the country.

\subsection{Data collection}

The "self-rating scale of self-directed learning" was adopted to determine the impact of Edmodo-supported reflective teaching applications on the self-directed learning skills of the prospective teachers. On the other hand, an "interview form" was used to collect information on the prospective teachers' opinions regarding the application.

Self-rating scale of self-directed learning (SRSSDL). The "self-rating scale of self-directed learning" scale is composed of 5 dimensions, which are "awareness", "learning strategies", "learning activities", "evaluation" and "interpersonal skills" with a total of 60 items, and was developed by Williamson in 2007 [33]. Each dimension is measured by 12 items on a 5-point scale, ranging from 5 (always) to 1 (never). The Cronbach's alpha value is calculated $(0.94)$ for the entire scale. The scale used for this current research has score intervals between 60 and 300. The score intervals and levels of the scale are given in Table 1 below.

Table 1. Self-Rating Scale of Self-Directed Learning

\begin{tabular}{|l|l|}
\hline $60-140$ & Self-directed learning levels "Low" \\
\hline $141-220$ & Self-directed learning levels "Moderate" \\
\hline $221-300$ & Self-directed learning levels "High" \\
\hline
\end{tabular}

As can be seen in Table 1, the learners whose score intervals were between 60 and 140 were interpreted to be learners with low self-directed learning levels, whereas those who scored between 141 and 220 were considered to be demonstrating improvement for their self-directed learning levels. Finally, the learners who scored between 221 and 300 were evaluated as learners with high levels of self-directed learning and were therefore defined as self-directed learners. On this point, Williamson [33] claimed that learners with low self-directed learning levels require teacher guidance. Learners whose self-directed learning levels demonstrate improvement should identify their deficiencies and employ strategies incorporating teacher guidance where appropriate. Williamson [33] continued by emphasizing that learners whose self-directed learning levels are high and are defined as self-directed learners should develop strategies in order to progress.

Interview form. At the end of the applications that lasted 12 weeks, a semistructured interview form designed by the researchers was used as an instrument to collect information on the views of the prospective teachers regarding the applications and the social learning platform Edmodo. In the face-to-face interviews, the intention was to determine the attitudes and views of the prospective teachers. The interviews lasted between 10 and 15 minutes. 


\subsection{Data analysis}

In the research, percentage, mean, standard deviation and paired samples statistical techniques were used in order to analyse the quantitative data. The values obtained at the end of the analysis were interpreted at a 0.05 significance level. For the qualitative data obtained through the interview forms, the "critical friends" approach was employed in order to ensure "trustworthiness". Following that, while one of the researchers was conducting the first analysis (text analysis), the other researcher performed double-checking. Finally, the qualitative data obtained from the interviews with the prospective teachers was analysed using the in-depth content analysis technique.

\subsection{Preparing the educational environment for Edmodo}

Edmodo, which is a social learning platform, was used in the reflective teaching applications that lasted 12 weeks. Before the applications commenced, the researchers formed groups by identifying the group name, the classroom level, the subject area and the group size. Also, all the prospective teachers who participated in the research were provided 3 hours of training by the researchers regarding the use of the Edmodo platform. Following that, the prospective teachers were able to access the Edmodo platform and become a group member by entering the group code generated by the researchers. Throughout the application, areas such as "writing notes", "library", "assignment", "announcement", and "discussion" were used in the Edmodo educational platform. Turkish was used for the Edmodo application, since the mother tongue of the prospective teachers was also Turkish. A screen capture demonstrating the Edmodo educational platform is provided below in Figure 1.

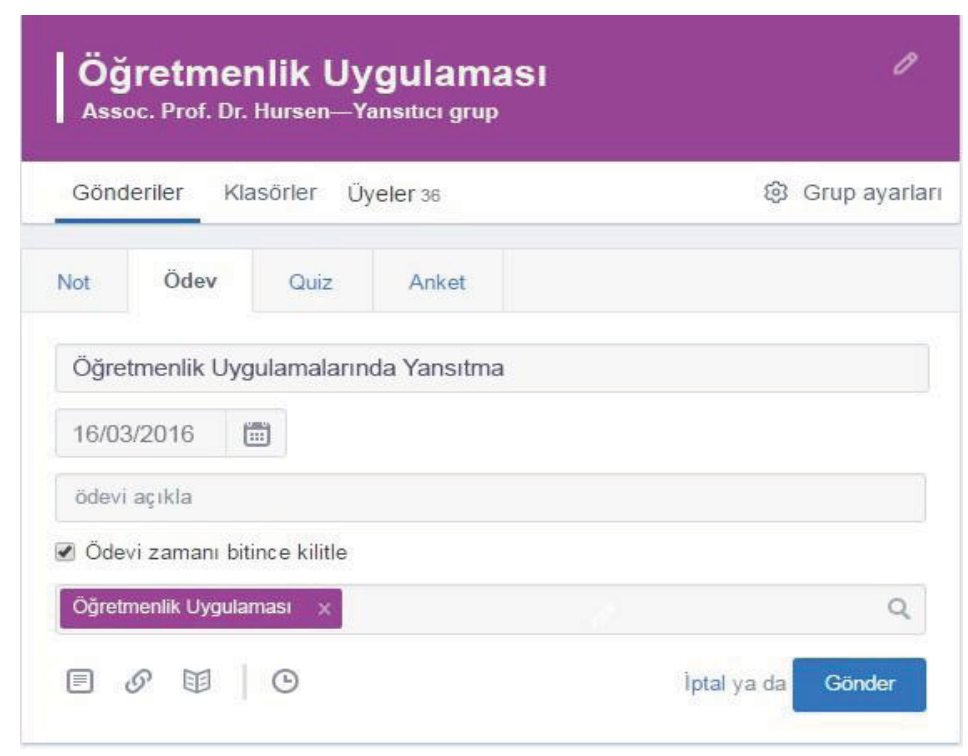

Fig. 1. Edmodo application 


\subsection{Application}

The application started in March, 2016 and lasted 12 weeks. The research was conducted within the scope of the Teacher Practice course. The research was implemented in a classroom setting where face-to-face interactions took place in conjunction with the environment established through the Edmodo platform. In other words, the research was performed in a blended learning environment. At the beginning of the application process, a pre-test self-directed learning scale was given to the prospective teachers who participated in the research in order to assess their self-directed learning skills. Also, a meeting was held to inform the participants on how to use the Edmodo platform. The main reason why the research was conducted within the scope of the "Teaching Practice" course is that this particular course offers the opportunity for the prospective teachers to transform their theoretical knowledge regarding the teaching profession into practice. Throughout the 12-week application, the prospective teachers not only performed activities in the classroom environment, but also through the Edmodo platform. In the applications, where only one of the researchers was authorised, all the announcements, assignments and sources including knowledge regarding the prospective teachers, were shared through Edmodo. Additionally, the notes and feedback regarding the files loaded for the assignments to be completed by the prospective teachers were shared through the Edmodo platform. Again, the prospective teachers shared knowledge with each other by initiating discussions and interpretations with regard to their projects that they shared over the Edmodo platform. In the face-to face classroom environment, however, the prospective teachers had the opportunity to record what they had learnt and to reflect their learning by completing a double entry journal, which is one of the reflective teaching techniques. Additionally, the researcher shared questions through the Edmodo platform regarding the subjects that were taught in the classroom environment. Following that, the participants were asked to think about the aforesaid questions and to produce reports that were inclusive of the learning reflections. At the end of the 12-week application, all the participants who participated in the research completed the post-test self-directed learning scale. Furthermore, face-to-face interviews were conducted with the volunteer teachers, whose feelings and opinions regarding the research were investigated.

\section{$3 \quad$ Results}

The findings of the research in line with the aims are given in the following section.

\subsection{Findings Regarding the Self-Directed Learning Levels of the Prospective Teachers}

The paired sample t-test analysis technique was applied to determine the impact of the Edmodo-supported reflective teaching applications on the self-directed learning skills of the prospective teachers. The findings of the research that indicate whether 
there is a significant difference in the self-directed learning skills of the prospective teachers or not after the application are shown in Table 2.

Table 2. Self-Directed Learning Levels of the Prospective Teachers Before and After the Application

\begin{tabular}{|l|l|l|l|l|l|l|l|}
\hline & & N & Mean & SD & df & t & p \\
\cline { 1 - 9 } $\begin{array}{l}\text { Edmodo supported } \\
\text { reflective teaching group }\end{array}$ & Pre-test & 36 & 196.61 & 21.160 & \multirow{2}{*}{35} & -14.497 & .000 \\
\cline { 2 - 9 } & Post-test & 36 & 254.63 & 12.147 & & & \\
\hline
\end{tabular}

*Significant at the .05 level of confidence

Prior to the application of Edmodo-supported reflective teaching, the prospective teachers considered their self-directed learning skills to be moderate $(M=196.61$, $\mathrm{sd}=21.160$ ); however, afterwards, they rated their self-directed learning skills as high $(\mathrm{M}=254.63, \mathrm{sd}=12.147)$. The results of the research indicate that Edmodo-supported reflective teaching applications are effective for teacher education and can improve the self-directed learning skills of the prospective teachers. The results of the research show that the prospective teachers who required improvement in certain areas prior to the application, demonstrated such improvement in the aforementioned areas when the application was completed. For instance, while the prospective teachers rated themselves at the moderate level $(\mathrm{M}=3.21, \mathrm{sd}=.449)$ regarding the "awareness" dimension, with statement such as "I identify my own learning needs", "I am able to select the best method for my own learning", "I am responsible for my own learning" and "I am able to maintain self-motivation", afterwards, they considered themselves to be adequate $(M=4.35, \mathrm{sd}=277)$. Again, prior to the application, the prospective teachers rated their skills as moderate $(\mathrm{M}=3.34, \mathrm{sd}=.580)$ with regards to the dimension of "learning strategies", consisting of statements such as "I participate in group discussions", "I am able to decide my own learning strategy" and "I find simulation in teaching-learning useful". Nevertheless, at the end of the application, they considered their skills to be adequate $(M=4.35, \mathrm{sd}=.365)$. Similarly, regarding the "learning activities" dimension, with statements including "I rehearse and revise new lessons", "I am able to use information technology effectively" and "I am able to relate knowledge with practice", the prospective teachers rated their skills at a moderate level $(\mathrm{M}=3.19, \mathrm{sd}=.602)$ prior to the application. However, their skills reached an adequate level $(\mathrm{M}=3.99, \mathrm{sd}=.564)$ at the end of the application. Furthermore, prior to the application, regarding the "evaluation" dimension, consisting of statements like "I am able to monitor my learning progress" and "I review and reflect on my learning activities", the skill levels of the prospective teachers were found to be moderate $(\mathrm{M}=3.22, \mathrm{sd}=.456)$, while this level rose $(\mathrm{M}=3.92, \mathrm{sd}=.392)$ after the application ended. Finally, with regards to the dimension of "interpersonal skills", including the statements such as "I need to share information with others" and "I am able to identify my role within a group", the prospective teachers rated their skills at a moderate level $(\mathrm{M}=3.40, \mathrm{sd}=.444)$ before the application commenced. However, their skill levels rose in a similar manner to the other dimensions $(\mathrm{M}=4.59, \mathrm{sd}=.306)$. This shows that the self-directed learning levels of the prospective teachers displayed a positive in- 
crease in the Edmodo learning platforms where reflective teaching activities were performed.

\subsection{Views of the Prospective Teachers Regarding the Edmodo-Supported Reflective Teaching Applications}

In the research, the aim was also to determine the views of the prospective teachers who participated in the Edmodo-supported reflective teaching applications with regards to both the Edmodo platform and the activities performed on the platform. Particular attention was paid to the opinions of the prospective teachers in terms of their feelings and thoughts at the end of the application. The qualitative data obtained from the interviews were classified under two main themes: "The place of Edmodo platform in teacher education" and "The importance of reflective teaching activities". The prospective teachers who participated in the Edmodo-supported reflective teaching activities for 12 weeks stated that they were relatively satisfied with the activities performed within the scope of the Teacher Practice course. Additionally, the prospective teachers gave positive evaluations about their Edmodo-supported reflective teaching experiences. In this regard, they identified that the Edmodo platform provided them with an active learning atmosphere. The majority of the prospective teachers believed that the Edmodo platform is extremely easy in terms of use, is supportive for teacher education and addresses more than one learning style. Again, more than half of the prospective teachers expressed that the activities performed over the Edmodo platform complemented those that were conducted on a face-to-face basis within the classroom setting. One of the prospective teachers who participated in the research expressed her views with the statement: "our learning becomes permanent when the theoretical knowledge we get within the classroom is supported by videos and pictures over the Edmodo platform". Some of the prospective teachers, nevertheless, claimed that having group discussions regarding the Teaching Practice over the Edmodo platform increased the learners' motivation. Some of the prospective teachers, conversely, stated that they enjoyed sharing their projects with the others, evaluating the projects that were shared and sending notes through the Edmodo platform. One of the prospective teachers expressed his views saying: "I found the opportunity to follow the projects of my friends as soon as they shared them on the Edmodo platform". Another prospective teacher expressed her satisfaction with regards to the Edmodo platform with these words: "I was able to communicate with my course teacher and class mates easily whenever and wherever I wanted". As the statements above clearly argue, the prospective teachers were satisfied with the use of the Edmodo platform in teacher education. Again, the use of Edmodo platform in teacher education is considered to be an advantage, particularly for the teaching of courses based on practice.

The prospective teachers who participated in the research emphasised that, like the Edmodo platform, the reflective teaching activities are also essential in teacher education. Almost all the prospective teachers believed that the reflective teaching activities are exceptionally useful for courses based on practice, such as Teaching Practice. Furthermore, it was claimed by the participants that the reflective teaching activities are unordinary and are significantly more effective when compared to the traditional 
methods. One of the prospective teachers who asserted the significance of the reflective teaching activities stated her views by saying: "these activities that I have never come across before made me feel like a real teacher". Another prospective teacher declared his views on this issue saying: "throughout the Teacher Practice course, I was quite active in carrying out activities and this had a positive impact on my motivation. I participated in all my classes happily and willingly". Therefore, it is apparent that the reflective teaching applications help to establish a link between theory and practice. Also, the aforementioned applications are influential for motivation with regards to learning.

\section{Discussion and Conclusion}

The research results reveal that the Edmodo-supported reflective teaching applications are positive in terms of the improvement of the prospective teachers in the teaching process and the results obtained. The results of the research demonstrate that the reflective teaching applications have improved the self-directed learning skills of the prospective teachers who took the Teaching Practice course. While the selfdirected learning skills of the prospective teachers were at a moderate level prior to the research, the level of the self-directed skills reached a high level at the end of the 12-week application. This reveals that both Edmodo and the reflective teaching application, which is one of the contemporary teaching techniques, are influential in teacher education. Likewise, Ozdamli [34] in her research with regard to online learning platforms, found similar results. Again, Koçdar [22] in his study, found that online learning platforms play a significant role in the improvement of learners' self-directed learning skills. Khodary [29] used Edmodo in order to improve university students' self-directed learning levels. In this research, where the impact of the Edmodo platform upon students was investigated, a semi-experimental design was employed. The findings of the research revealed that the Edmodo applications created a significant difference in the self-directed learning levels of the university students. Khodary [29], therefore, in his research found that Edmodo helps university students to improve their self-directed learning levels. Charoenwet and Christensen [35], on the other hand, conducted a study with students, planning to facilitate the communication between students and teachers and encourage participation in classroom activities. Furthermore, Charoenwet and Christensen aimed to determine the students' selfregulated learning levels at the end of the Edmodo application. The students who participated in the study performed Edmodo activities by registering in the Edmodo classroom. The results of the study indicated that the learning activities provided through the Edmodo platform created a positive impact upon the students' selfregulated learning levels as well as their perceptions regarding online learning. Resultantly, Charoenwet and Christensen [35] argued that the Edmodo platform significantly improves students' learning performance. On the other hand, Köksal and Demirel [36] favoured a different viewpoint. Placing emphasis on the reflective teaching activities, Köksal and Demirel [36] argued that the aforesaid activities have a positive impact on the planning, applying and evaluating processes of the prospective teachers. 
Similarly, Tok [37] in his study, found that reflective teaching activities are considerably effective on prospective teachers' performance. In 2014, Selmo and Orsenigo [38] conducted research with prospective teachers and found that the reflective teaching applications are an effective learning tool in teacher education. Finally, it could be concluded that, not only the Edmodo platform but also the reflective teaching activities are effective for teacher education and can assist with the development of the selfdirected learning skills of prospective teachers.

Another finding of the research is that the prospective teachers were satisfied with the Edmodo-supported reflective teaching applications. In their research, Gómez et al. [39] found that students were positive about the Edmodo platform and were satisfied with its functionality. Furthermore, the findings of the research conducted by Gómez et al. [39] indicated that there was a positive relationship between the students' satisfaction levels and their academic results. Therefore, the findings of Gómez et al. [39]'s research are in line with the findings of this current research.

The participants identified that the Edmodo platform has an important role in teacher education. The prospective teachers, as the participants of this current research, claimed that their motivation increased and the course became more enjoyable and effective when the activities were supported with the Edmodo platform. Trust [40], in his study that was conducted with teachers, reached similar results and he defined Edmodo as an effective professional learning networks and stated that Edmodo is an interesting and beneficial platform. The findings of the study revealed that Edmodo, which is a safe platform that enables students to ask questions to their teachers, share sources and learn from other members, can be motivational for teachers. Again, Manowong [41] in her study, reached similar results to that of Trust [40]. Manowong [41] stated that Edmodo has several characteristics that support the students' learning process, and it complements the traditional learning environment. Manowong [41] who asserted that Edmodo is a beneficial learning tool, found that students' motivation as well as participation in the learning activities improved in a positive way. The findings of the study conducted by Manowong [41] support the findings of this current research. The findings revealed that the Edmodo platform has the capability of eliminating the limitations of the traditional learning environment and can increase learners' motivation. Also, communication between the teacher and learners is strengthened with the Edmodo platform. Alemdağ [42] in his study, underlined the necessity that teachers should be informed and trained regarding the use of Edmodo, which is widely acknowledged as online educational social learning platform. Alemdağ [42] in his study, emphasised that the Edmodo platform can be beneficial during the teaching period. Another finding of Alemdağ [42] in the same study, was that Edmodo strengthens communication. Therefore, the findings of Alemdag [42] are in line with the findings of this current research. Warawudhi [43] in his research conducted in 2017, reached similar findings. In his research conducted with 54 undergraduate students, Warawudhi [43] investigated the attitudes of students regarding the use of Edmodo. Also, he intended to examine the problems experienced when using Edmodo to identify the recommendations of the students. The findings showed that the students had positive attitudes towards Edmodo. Also, Warawudhi [43] found that interaction was established between the students and the teacher at the end of the 
research. Again, Krutka et al. [44] conducted a research study aimed at improving collaborative reflection among 77 pre-service teachers by using the Edmodo platform. Krutka et al. [44] claimed that the Edmodo is generally user friendly, encourages interaction between peers and improves the collaborative reflection of students and teachers. Similarly, Batsila et al. [27] intended to investigate teachers' views regarding Edmodo in their research. The findings of the research that was conducted with the participation of 41 teachers indicated that the teachers were considerably satisfied with the Edmodo platform. The findings obtained from Batsila et al.'s [27] research are consistent with the findings of this current research. Furthermore, Batsila et al. [27] stated that the teachers in their research perceived the Edmodo platform to be a motivational environment for students.

Song and Kong [45], on the other hand, attempted to determine the teachers' views regarding "Bring Your Own Device" for learning and teaching in 2017. The 17 teachers who participated in the research took part in similar applications by following different courses. For example, while 8 of the teachers chose Moodle, 6 of them preferred Edmodo as a social learning platform. At the end of the research, the teachers stated that they had the opportunity to connect with their students and were able to participate in learning activities on the Edmodo social network platform throughout the course, regardless of time or place. Also, Song and Kong [45] in their research, argued that the participating teachers stated that the online learning activities improved their students' reflective thinking and their pedagogical patterns. The findings of Song and Kong [45] are consistent with the findings of this current research.

Wichadee [15] conducted a study in 2017 where he used Edmodo as a learning tool in a language learning process and investigated the impact of Edmodo upon oral proficiency, motivation and attitudes regarding a students' English lesson. The study included 42 students who were all taking the English lesson. In the control group of the study, students performed face-to-face learning, while in the experimental group of the study, students used Edmodo. The findings revealed that the blended learning environment is more efficient than the traditional learning environment. Wichadee [15] claimed that the students in the experimental group demonstrated progress regarding their oral proficiency, motivation and attitudes at the end of the application and the students developed positive attitudes towards Edmodo. Another finding of this research is that the prospective teachers considered the reflective teaching activities that were performed in teacher education to be significant. According to the prospective teachers, the Edmodo-supported reflective teaching activities helped to establish a link between theoretical knowledge and practice that take place in teacher education. Duban and Yelken [46], in their study, emphasised the crucial role of reflective teaching activities in teacher education. They also paid particular attention to the link between cognitive knowledge and practice.

In conclusion, it is recommended that different teaching applications should be designed with the intention of improving teacher education and enabling the prospective teachers to gain various professional skills. Furthermore, it is recommended that the findings obtained from this research should be discussed in accordance with the findings of future studies. 


\section{$5 \quad$ References}

[1] M. A. Flores, "Curriculum of initial teacher education in Portugal: new contexts, old problems," Journal of Education for Teaching: International research and pedagogy, vol. 37, no. 4, pp. 461-470, 2011.

[2] De Jong, "Towards tomorrow's education: Involving (student) teachers, teacher trainers, and curriculum designers in authentic learning communities," In Keynote lecture at the Hashemite University conference 'Education in a Changing World', Zarqa, Jordan, 2010.

[3] H. Özçınar, "Mapping teacher education domain: A document co-citation analysis from 1992 to 2012," Teaching and Teacher Education, vol. 47, pp. 42-61, 2015. https://doi.org/10.1016/j.tate.2014.12.006

[4] T. Seidel et al., "Instructional strategies for using video in teacher education," Teaching and Teacher Education, vol. 34, pp. 56-65, 2013. https://doi.org/10.1016/ j.tate.2013.03.004

[5] A. Potts and K. A. Schlichting, "Developing professional forums that support thoughtful discussion, reflection, and social action: One faculty's commitment to social justice and culturally responsive practice," International Journal of Teaching and Learning in Higher Education, vol. 23, no. 1, pp. 11-19, 2011.

[6] R. A. Ellis et al., "University teacher approaches to design and teaching and concepts of learning technologies," Teaching and Teacher Education, vol. 25, pp. 109-117, 2009. https://doi.org/10.1016/j.tate.2008.06.010

[7] L. D. Hammond, “Constructing 21st-century teacher education," Journal of Teacher Education, vol. 57, no. 10, pp. 1-15, 2006.

[8] J. Colomer et al., "Reflective learning in higher education: A comparative analysis," Procedia - Social and Behavioral Sciences, vol. 93, pp. 364-370, 2013. https://doi.org/10.1016/j.sbspro.2013.09.204

[9] M. Ryan and M. Ryan, "Theorising a model for teaching and assessing reflective learning in higher education," Higher Education Research \& Development, vol. 32, no. 2, pp. 244257, 2012. https://doi.org/10.1080/07294360.2012.661704

[10] H. C. Liou, "Reflective practice in a pre-service teacher education program for high school English teachers in Taiwan, ROC,” System, vol. 29, pp. 197-208, 2001. https://doi.org/10.1016/S0346-251X(01)00011-2

[11] C. Kilpatrick et al., "Reflective teaching practice by University Faculty: Rationale and case study in computer science," Frontiers in Education Conference, $27^{\text {th }}$ Annual Conference, Teaching and Learning in an Era of Change, Proceedings 3, 1997. https://oi.org/10.1109/ FIE.1997.632638

[12] J. G. Henderson, "Reflective teaching: Becoming on inquiring educator," New York: McMillan, 1992.

[13] S. Galea, "Reflecting reflective practice," Educational Philosophy and Theory: Incorporating ACCESS, vol. 44, no. 3, pp. 245-258, 2012. https://doi.org/10.1111/j.14695812.2010.00652.x

[14] F. Sarsar et al., "Use of social media in learning and teaching process," Mersin University Journal of the Faculty of Education, vol. 11, no. 2, 2015.

[15] S. Wichadee, "A development of the blended learning model using Edmodo for maximizing students' oral proficiency and motivation," Ijet, vol. 12, no. 2, pp. 137-154, 2017.

[16] E. Ceker and F. Ozdamli, "Features and characteristics of problem based learning," Cypriot Journal of Educational Science, vol. 11, no. 4, pp. 195-202, 2016. https://doi.org/10.18844/cjes.v11i4.1296 
Paper-The Impact of Reflective Teaching Applications Supported by Edmodo on Prospective Teach...

[17] H. Bicen, "The role of social learning networks in mobile assisted language learning: Edmodo as a case study," Journal of Universal Computer Science, vol. 21, no. 10, pp. 1297$1306,2015$.

[18] H. Bicen and H. Uzunboylu, "The use of social networking sites in education: A case study of Facebook," J. UCS, vol. 19, no. 5, pp. 658-671, 2013.

[19] Y. Gülbahar et al. (2010). "Sosyal ă̆ların eğitim amaçlı kullanımı," Available: http:/orcun.madran.net/yayinlar/sosyal aglarin egitim amacli kullanimi.pdf

[20] C. Murray, "Schools and social networking: Fear or education?," Synergy Perspectives: Local, vol. 6, no. 1, pp. 8-12, 2008.

[21] R. E. Ferdig, "Editonial: Examining social software in teacher education," Journal of Technology and Teacher Education, vol. 15, no. 1, pp. 5-10, 2007.

[22] S. Koçdar, "Çevrimiçi ortamlarda öğrenenlerin öz-yönetim becerilerinin geliştirilmesinde kullanılan stratejiler ve araçlar," AUAd, vol. 1, no. 1, pp. 39-55, 2015.

[23] S. G. L. Won et al., "Youth appropriation of social media for collaborative and facilitated design-based learning," Computers in Human Behavior, vol. 50, pp. 385-391, 2015. https://doi.org/10.1016/j.chb.2015.04.017

[24] M. Sarrab et al., "Towards a quality model of technical aspects for mobile learning services: An empirical investigation," Computers in Human Behavior, vol. 55, pp. 100-112, 2016. https://doi.org/10.1016/j.chb.2015.09.003

[25] A. A. Okaz, "Integrating blended learning in higher education," Procedia - Social and Behavioral Sciences, vol. 186, pp. 600 - 603, 2015. https://doi.org/10.1016/j.sbspro. 2015.04.086

[26] T. Trust et al., "Together we are better": Professional learning networks for teachers," Computers \& Education, vol.102, pp. 15-34, 2016. https://doi.org/10.1016/j.compedu. 2016.06.007

[27] M. Batsila et al., "Entering the Web-2 Edmodo world to support learning: Tracing teachers' opinion after using it in their classes," iJET, vol. 9, no. 1, 2014.

[28] W. Banyen et al., "A blended learning model for learning achievement enhancement of Thai undergraduate students," iJET, vol.11, no. 4, 2016.

[29] M. M. Khodary, "Edmodo use to develop Saudi EFL students' self-directed learning," English Language Teaching, vol. 10, no. 2, 2017. https://doi.org/10.5539/elt.v10n2p123

[30] T. Lehmann et al., "Cognitive, metacognitive and motivational perspectives on reflection in self-regulated online learning," Computers in Human Behavior, vol. 32, pp. 313-323, 2014. https://doi.org/10.1016/j.chb.2013.07.051

[31] L. Barnard-Brak et al., "Profiles in self-regulated learning in the online learning environment," International Review of Research in Open and Distance Learning, vol. 11, no. 1, pp. 61-80, 2010. https://doi.org/10.19173/irrodl.v11i1.769

[32] Z. Ali, "A case study of tertiary students "experiences using Edmodo in language learning," International Journal of Language Education and Applied Linguistics (IJLEAL), vol. 2, pp. 39-48, 2015.

[33] S. N. Williamson, "Development of a self-rating scale of self-directed learning," Nurse Researcher, vol. 14, no. 2, pp. 66-83, 2007. https://doi.org/10.7748/nr2007.01. 14.2.66.c6022

[34] F. Ozdamli, "Effectiveness of cloud systems and social networks in improving selfdirected learning abilities and developing positive seamless learning perceptions," Journal of Universal Computer Science, vol. 18, no. 5, pp. 602-618, 2013.

[35] S. Charoenwet and A. Christensen, "The effect of Edmodo learning network on students' perception, self-regulated learning behaviors and learning performance," Proceedings of The 10th International Multi-Conference on Society, Cybernetics and Informatics, 2016. 
Paper-The Impact of Reflective Teaching Applications Supported by Edmodo on Prospective Teach...

[36] N. Köksal and Ö. Demirel, "Yansıtıcı düşünmenin öğretmen adaylarının öğretmenlik uygulamalarına katkıları," Hacettepe Üniversitesi Eğitim Fakültesi Dergisi, vol. 34, pp. 189203, 2008.

[37] S. Tok, "The impact of reflective thinking activities on student teachers' attitudes toward teaching profession, performance and reflections," Education and Science, vol. 33, no. 149, 2008.

[38] L. Selmo and J. Orsenigo, “, Learning and sharing through reflective practice in teacher education in Italy," Procedia - Social and Behavioral Sciences, vol. 116, pp. 1925-1929, 2014. https://doi.org/10.1016/j.sbspro.2014.01.496

[39] A. Gómez et al., "UX of social network Edmodo in undergraduate engineering students," International Journal of Interactive Multimedia and Artificial Intelligence, vol. 3, no. 4, pp. 31-36, 2015. https://doi.org/10.9781/ijimai.2015.346

[40] T. Trust, "Professional learning networks designed for teacher learning," Journal of Digital Learning in Teacher Education, vol. 27, no. 1, pp. 34-38, 2012. https://doi.org/10.1080/21532974.2012.10784693

[41] S. Manowong, "Undergraduate students' perceptions of Edmodo as a supplementary learning tool in an EFL classroom," Silpakorn University Journal of Social Sciences, Humanities, and Arts, vol. 16, no. 2, pp. 137-161, 2016.

[42] E. Alemdağ. (2014). "Edmodo: Eğitsel bir çevrimiçi sosyal öğrenme ortamı," Available: http://inet- tr.org.tr/inetconf18/bildiri/28.pdf

[43] R. Warawudhi, "The evaluation of Edmodo in business reading class," International Journal of Information and Education Technology, vol. 7, no. 2, 2017. https://doi.org/10.18178/ijiet.2017.7.2.858

[44] D. G. Krutka et al., "Microblogging about teaching: Nurturing participatory cultures through collaborative online reflection with pre-service teachers," Teaching and Teacher Education, vol. 40, pp. 83-93, 2014. https://doi.org/10.1016/j.tate.2014.02.002

[45] Y. Song and S. C. Kong, "Affordances and constraints of BYOD (Bring Your Own Device) for learning and teaching in higher education: Teachers' perspectives," Internet and Higher Education, vol. 32, pp. 39-46, 2017. https://doi.org/10.1016/j.iheduc.2016.08.004

[46] N. Duban and T. Y. Yelken, "Öğretmen adaylarının yansıtıcı düşünme eğilimleri ve yansıtıcı öğretmen özellikleriyle ilgili görüşleri,” Ç.Ü. Sosyal Bilimler Enstitüsü Dergisi, vol. 19 , no. 2 , pp. 343-360, 2010.

\section{Authors}

Cigdem Hursen works as an associate professor at Near East University. In October 2013, she was appointed to be the chairperson of the department of Social Sciences of Near East University, Atatürk Education Faculty. In the same year, she was also appointed as the chairperson of the department of Measurement and Evaluation. She is also one of the board members of the Association of Cyprus Educational Sciences.

Funda Gezer Fasli is a PhD student at Division of Curriculum and Instruction, Near East University. Also, she is a lecturer at Near East University, Atatürk Education Faculty.

Article submitted 10 April 2017. Published as resubmitted by the authors 16 June 2017. 